\title{
GENDER PERSPEKTIF ETIKA PESANTREN (Studi Tentang Kepemimpinan Kiai dan Nyai Tentang Sosialisasi Gender di Lingkungan Sosial Pondok Pesantren Wahidhasyim Sleman Yogyakarta)
}

\author{
Erfan Efendi \\ Dosen Fakultas Tarbiyah dan Ilmu Keguruan FTIK-IAIN Jember \\ efendi.e89@gmail.com
}

\begin{abstract}
Gender socialization in pesantren is a top priority because gender construction in pesantren is very dependent on how gender identity is also formed through bow strong the socialization process is. The identity formed in the pesantren will then become a reference for the students to socialize or interact with the environment outside the pesantren. From that, the issue of gender or equal partnerships between men and women, which was previously known as the increase in the position of the role of women in Islam, has increasingly attracted a lot of progress and success. There are two orientations in socializing gender in pesantren, namely: first, strengthening the normativity of gender roles. This role is performed by most of the kyai, nyai, and teachers. Second, prioritizing gender role textuality. This motive is carried out by a small number of madrasah teachers and badal kyai and nyai when conducting recitation at the pesantren. The problem is the focus of this research discussion. First, what is the role of kyai and nyai leadership in gender socialization at the Wabid Hasyim Islamic boarding school, Sleman Yogyakarta. Second, how to implement gender criteria in the regulations of the Wabid Hasyim Sleman Yogyakarta Islamic boarding school. Third, how is the implementation of the santri behavior of the Wabid Hasyim Sleman Yogyakarta Islamic boarding school.
\end{abstract}

\section{Keywords: Gender, Islamic Boarding Schools, Gender Socialization Agents in Pesantren}

\section{Abstrak}

Sosialisasi gender di pesantren menjadi prioritas utama sebab konstruksi gender yang ada di pesantren sangat bergantung pada bagaimana identitas gender juga dibentuk melalui seberapa kuat proses sosialisasinya. Identitas yang terbentuk di pesantren selanjutnya akan menjadi acuan para santri 


\section{Erfan Efendi}

untuk bermasyarakat ataupun berinteraksi dengan lingkungan di luar pesantren. Dari itu, persoalan gender atau kemitra sejajaran antara lakilaki dan perempuan yang sebelumnya dikenal dengan peningkatan kedudukan peran perempuan dalam Islam semakin menarik banyak kemajuan dan keberhasilan.Terdapat dua orientasi dalam mensosialisasikan gender di pesantren, yaitu: pertama, menguatkan normativitas peran-peran gender. Peran ini dilakukan oleh sebagian besar para kyai, nyai, dan guru. Kedua, mengedepankan tekstualitas peran gender. Motif ini dilakukan oleh sebagian kecil guru madrasah dan badal kyai serta nyai ketika melakukan pengajian di pesantren. Adapun problem yang menjadi fokus pembahasan penelitian ini. Pertama, Bagaiman peran kepemimpinan kyai dan nyai dalam sosialisasi gender di pesantren Wahid Hasyim Sleman Yogyakarta. Kedua, Bagaimana implementasi kesteraan gender dalam peraturan pesantren Wahid Hasyim Sleman Yogyakarta. Ketiga, bagaimana implementasi pada perilaku santri pesantren Wahid Hasyim Sleman Yogyakarta.

\section{Kata Kunci : Gender, Pesantren, Agen Sosialisasi Gender di Pesantren}

\section{Pendahuluan}

Pesantren memiliki tradisi yang kuat dalm mensosialisasikan nilai-nilai dan menurunkan pemikiran para pendahulunya dari generasi ke generasi. Para pemimpin pesantren, yaitu kiai dan nyai, adalah tokoh utama dalam proses ini. Tranmisi ilmu yang dilakukan oleh para kiai dan nyai berlangsung secara monolog, mengingat posisi tradisional mereka sebagai pemegang otoritas keagamaan. ${ }^{1} \quad$ Oleh karena itu tranmisi keilmuan yang berlangsung di pesantren lebih bersifat dogmatis dan idiologis.

Pondok pesantren sebagai pusat transmisi dan diseminasi ilmu-ilmu keislaman selama ini sering dikesankan sebagai sarang konservatisme, kejumudan dan cenderung eksklusif karena resisten terhadap nilai-nilai yang da-

1 Abdurrahman wahid, "Martin Van Bruinessen dan pencariannya" pengantar pada Martin Van Bruinessen, pesantren dan tarikat (Bandung: Mizan, 1995). hlm.11-12 


\section{Erfan Efendi}

tang dari luar, ${ }^{2}$ termasuk di dalamnya nilai-nilai feminisme yang memperjuangkan kesetaraan gender antara laki-laki dan perempuan. Karena eksklusifitasnya ini, pendidikan pesantren masih sarat dengan nilai-nilai yang bias gender.

Pesantren sejak awal 70-an telah menjadi subjek yang luas bagi penelitian social, dan menarik perhatian para akademisi dari sudut pandang sejarah, sosiologi, politik, linguistic dan antropologi. Namun relevansi isu gender dengan berbagai aspek kehidupan social di pesantren belum mendapat perhatian yang memadai dan baru muncul belakangan dalam cakupan yang terbatas. Penelitian desertasi Zamakhsyyari Dhofier pada tahun 1980-an dpat dikatakan sebagai penelitian komprehensif pertama tentang pesantren. Sebagaiman yang termaktub dalam sebagian isi

\footnotetext{
${ }^{2}$ Nurcholish Madjid, Bilik-Bilik Pesantren: Sebuah Potret Perjalanan (Jakarta: Paramadina, 1997).hlm. 90
}

desertasinya yang berjudul, “....studi tentang pandangan hidup kiai", ${ }^{3}$ dalam kajian ini Zamakhsyari Dhofier sepenuhnya adalah posisi dan peran kiai dalam kehidupan sosio-religius dalam perkembangan pesantren. Dalam naskah asli yang berbahasa inggris, anak judul penelitiannya mengambarkan tujuan Zamakhsyyari Dhofier secara spesifik, “...A Study Of The Role Of The Kiai In The Maintenance Of The Tradisional Ideology Of Islam In Java..." Kiai Nampak sebagai pemain tunggal didukung sepenuhnya oleh jaringan kekerabatan, intelektual dan simbolik para kiai yang terjalin lintas pesantren dan lintas generasi para pimpinannya (yang lebih dikenal dengan istilah gus). Dalam hal ini, nyai tidak mendapat tem-

3 Zamakhsyari Dhofier, Tradisi Pesantren, (Jakarta: LP3ES, 1982), hlm. 21

${ }^{4}$ Zamakhsyari Dhofier, The Pesantren Tradition:A Study Of The Role Of The Kiai In The Maintenance Of The Tradisional Ideology Of Islam In Java, disertasi phD. Pada the Australian national university (cambera: The Australian National university, 1980). 
Vol. 13, No. 2, Oktober 2020

p-ISSN:2086 -0749

e-ISSN:2654-4784

pat bersama hilangnya perhatian pada isu gender dalam keseluruhan studi Dhofier.

Sebagai contoh dalam interaksi sosial budaya pesantren, perempuan sebagai mahkluk yang memiliki kekuatan intelektual dan kecepatan fisik yang lebih rendah dibanding dengan laki-laki.

Dilibat dari berbagai aturan titik beratnya kepada perempuan. Lakilaki jarang mendapat penekanan. Contohnya tentang persaksian, persaksian perempuan tidak kuat. Perempuan dua, laki-laki cukup satu. Apalagi saksisaksi lain. Saksi perbuatan zina harus empat laki-laki, jika perempuan maka jumlahnya harus delapan. Begitu juga dalam bab-bab waris dan bab-bab bukum lainnya. Pantas sebab tanggung jawab laki-laki lebih berat dan tanggung jawab perempuan lebih ringan ${ }^{5}$

Pembagian tugas, waris, dan persaksian dikategorikan tugas laki-laki. Laki-laki ditempatkan

\footnotetext{
${ }^{5}$ Wawancara dengan salah satu ustadah perempuan Ibu Masitoh di pondok pesantren Wahid Hasyim Sleman Yogyakarta. Pada tanggal 27 Desember 2016. Jam. 13.00
}

lebih superior dengan berbagai kelebihan fisik dan intelektualitasnya dibandingkan perempuan. Wilayah-wilayah publik dipandang pantas bagi laki-laki, sebab lakilaki kekuatannya dianggap dua kali lipat dibandingkan perempuan. Perempuan diidentifikasi sebagai makhluk yang inferior, bertanggung jawab pada wilayahwilayah domestik. Pemahaman bahwa laki-laki memikul dan perempuan cukup menjinjing mengganggap dunia laki-laki adalah dunia yang menyangkut superioritas. Perempuan menganggap dunianya yang inferior tidak diperlukan seperti kapasitas yang dimiliki laki-laki.

Menurut Dadang Anshari peran gender terjadi proses sosialisasi yang membentuk identitas gender yaitu pencitraan perilaku yang seharusnya dimiliki dan ditampilkan oleh seseorang menurut 


\section{Erfan Efendi}

jenis kelamin yang bersangkutan di pesantren. ${ }^{6}$ Oleh karena itu, jika terdapat perbedaan perilaku menurut jenis kelamin, yang bersangkutan dianggap sebagai penyimpangan perilaku. Peran perempuan dan peran laki-laki diaplikasikan dalam bentuk yang nyata menurut kultur yang dianut dan diterima di lingkungan pesantren.

Diskursus tentang gender merupakan wacana yang baru bagi dunia pesantren, dalam perkembangannya mengundang sikap resisten dan kontroversi karena dipandang sebagai unsur yang dating dari barat dan tidak berakar pada tradisi pesantren. Isu gender masuk dalam komunitas pesantren, diakui atau tidak, didorong oleh sensitivitas gender yang muncul sebagai sikap kritik atas berbagai kultural dalam tubuh pesantren. Rekonstruksi ini perlu

\footnotetext{
${ }^{6}$ Anshari, Dadang S (Ed.) dkk. 1997. Membincangkan Feminisme, Refleksi Muslimah atas Peran Sosial Wanita. Bandung: Pustaka Hidayah.hlm. 24
}

dilakukan dengan mempertimbangkan sarana-sarana kebudayaan yang bersumber dari pemaknaan teologis atas realitas sosial aktual. Dari latar belakang inilah yang mendasari pemilihan lokasi penelitian di pesantren $\mathrm{Wa}$ hid Hasyim Sleman Yogyakarta dengan mempertimbangkan peseantren sebagai representasi lembaga sosial yang utuh dan lengkap dengan batas-batas geografis, norma-norma sosial, perilaku khusus para kiai, nyai, ustad dan santri dan pengurus pesantren hidup bersama.

Kyai dan terutama sekali Nyai adalah tokoh-tokoh sentral di pesantren. Selain sebagai pimpinan, mereka adalah guru, teladan, dan sumber nasihat bagi para santri. Mereka memiliki peran yang substantial dalam mensosialisasikan konsep dan ajaran agama di pesantren. Hubungan antara kyai dan nyai dengan santri diikat oleh emosi keagamaan sedemikian rupa sehingga 
Vol. 13, No. 2, Oktober 2020

p-ISSN:2086 -0749

e-ISSN:2654-4784

setiap pandangan dan pendapat mereka adalah pegangan bagi para santrinya. Hubungan emosional keagamaan inilah yang membuat peran dan fungsi kyai dan nyai menjadi sangat kuat dalam mensosialisasikan nilai-nilai baru terhadap para santri.

Kaitannya dengan isu gender, lingkungan pesantren juga memiliki beberapa persoalan gender. Salah satu indikator utama persoalan gender di lingkungan pesantren adalah kesenjangan mencolok antara laki-laki dan perempuan. Misalnya saja pandangan masyarakat umum yang muncul saat ini, bahwa pesantren merupakan lembaga sosial yang diciptakan, dijalankan, dan dikembangkan oleh laki-laki dengan kyai dan ustadz sebagai kontributor utamanya. Posisi perempuan dalam dunia pesantren dianggap tid- ak penting, subordinatif atau tidak relevan.

Berdasarkan Tema yang akan dikaji, terdapat beberapa problem yang menjadi fokus pembahasan penelitian ini. Pertama, Bagaiman peran kepemimpinan kyai dan nyai dalam sosialisasi gender di pesantren Wahid Hasyim Sleman Yogyakarta. Kedua, Bagaimana implementasi kesteraan gender dalam peraturan pesantren Wahid Hasyim Sleman Yogyakarta. Ketiga, bagaimana implementasi pada perilaku santri pesantren Wahid Hasyim Sleman Yogyakarta. Ketiga fokus inilah yang akan dianalisis dalam reseach ini.

\section{Landasan Teori}

\section{Gender}

Kata gender secara etimologi bersal dari bahasa inggris, gen- 


\section{Erfan Efendi}

der, yang berarti “jenis kelamin".7

Gender adalah ciri-ciri yang membedakan laki-laki dan permpuan secara social budaya yang diciptakan oleh manusia itu sendiri. ${ }^{8}$ Pemgertian etimologis ini lebihg menekankan hubunagn laki-laki dan perempuan secara anatomi. Dalam Webster's New World Dictionary, gender diartikan sebagai perbedaan yang tampak anatara laki-laki dan p[erempuan dilihat dari segi nilai dan tingkah laku. ${ }^{9}$ Definisi ini lebih menekankan aspek cultural dibandindingkan pemaknaan secara anatomis. Di dalam Women's Studies Encyclopedia dijelaskan bahwa gender adalah suatu konsep culturalyang berupaya membuat perbedaan dalam peran. Perilaku, mentalitas dan karakteristik emosional antara

${ }^{7}$ John M. E chol dan Hasan Shadily, Kamus Inggris Indonesia (Jakarta: Gramedia, 1993), hlm. 296.

${ }^{8}$ Ratna Megawangi, Membiarkan Berbeda? Sudut pandang Baru Tentang Relasi Gender, cet. 2. (Bandung: Mizan, 1999), hlm 93.

${ }^{9}$ Victoria Neufeldt ed., Webster's New World Dictionary (NewYork: Webster's New World Clevenland, 1984), hlm. 561. laki-laki dan perempuan dan perkembangan dalam ,masyarakat. ${ }^{10}$ Menurut Jill Steal, term gender tidak ditunjukkan kepada perbedaan antara laki-laki dan perempuan secara biologis dan material secara eksistensi keduanya. Begitu juga term maskulin dan feminine bukan merupakan bawaan alami, melainkan terminology gender. ${ }^{11}$

Gender sebagai perspektif mempunyai berbagai asumsi dasar, model, konsep serta model, konsep serta metode yang digumakan untuk mengungkapkan dan menampilkan adanya fenomena gender dalam suatu masyarakat serta berbagai persoalan social budaya yang ditimbulkannya.Berdasarkan paparan doiatas gender didefinisikan sebagai suatu konsep cultural yang membedakan antara laki-laki dan perempuan dipandang dari

${ }^{10}$ Helen Tiemey ed., Women's Studies Encyclopedia, vol. 1. (New York: Gren Wood Press, ), hlm. 153.

${ }^{11}$ Jiil Steans, Gender and InternationalRelations (London: Polity, 1998), hlm. 10. 
Vol. 13, No. 2, Oktober 2020

p-ISSN:2086 -0749

e-ISSN:2654-4784

segi sosial budaya yang dapat berubah sesuai dengan perkembangan jaman. Perbedaan antara laki-laki dan perempuan dibedakan karena jenis kelamin. Ada tugas-tugas yang harus dipenuhi oleh keduanya. Akan tetapi pemahaman ini berawal dari kerancuan paradigm tentang gender differences dan sex differences sebagai perbedaan laki-laki dan perempuan. Sederhananya, gender dengan seks itu berbeda. Gender diidentifikasi sebagai perbedaan laki-laki dan perempuan dari aspek sosial dan budaya. Sementara perbedaaan seks digunakan untuk mengidentifikasi perbedaan lakilaki dan perempuan secara anatomis dan biologis. ${ }^{12}$

\section{Pesantren}

Pesantren atau pondok adalah lembaga yang merupakan

12 LisaLuttle, Encyclopediaof Feminism (New York: Facts on filepublication, 1986), hlm. 123. wujud proses perkembangan sistem perkembangan nasional. Dari segi historis pesantren tidak hanya identik dengan makna keislaman, testapi juga mengandung keaslian Indonesia (indigenous). ${ }^{13}$

Perkataan pesantren asal dari kata santri, dengan awalan pe di depan dan akhiran an berarti tempat tinggal para santri sedangkan asal-usul kata "santri", menurut A.H. John berasal dari bahasa tamil yang berarti guru ngaji. C.C. Berg juga berpendapat bahwa istilah santri berasal dari kata shastri (bahasa India) yang berarti orang yang tau buku-buku suci agama Hindu atau sarjana ahli kitab agama $\mathrm{Hindu}^{14}$. Jika diambil dari akar kata sastra artinya bukubuku suci, kitab agama atau bukubuku tentang Ilmu-ilmu penge-

13 Nurkholis Majid, Bilik-bilik Pesantren (Jakarta: paramadina), hlm.3.

14 Zanakhasary Dhofier, Tradisi Pesantren: Studi Pandangan Kyai Jakarta: LP3ES, 1994), hlm. 18. 


\section{Erfan Efendi}

tahuan. Pendapat kedua mengatakan bahwa perkataan santri sesungguhnya berasal dari bahasa Jawa, dari kata "Cantrik", berarti seseorang yang sesalalu mengikuti seorang guru kemana guru itu pergi menetap. ${ }^{15}$

Istilah pondok berasal dari Bahasa Arab (fundunk), dari pengertian asrama-asrama para santri yang dibuat dari bamboo, atau melihat dari asal kata Bahasa Arab fundunk, yang berarti hotel atau asrama. ${ }^{16} \mathrm{Imam}$ Azzarkazi berapendapat bahwa pesantern berarti tempat para santri, sedangkan santri berarti pelajaran yang menuntut ilmu agama Islam. ${ }^{17}$

Menurut Harun Nasution kata pesantren berasal dari kata santri yang mendapat imbuhan pean sehingga menjadi pesantrian

\footnotetext{
15Zanakhasary Dhofier, Tradisi Pesantren,.hlm. 21.

16Zanakhasary Dhofier, Tradisi Pesantren.,,hlm. 18.

${ }^{17}$ Gontor, Biografi KH. Imam Zarkasi dari Gontor Merintis Pesantren Modern (Ponorogo: Gontor Press, 1996), hlm. 55.
}

(pesantren). ${ }^{18}$ Menurut

Zamahhsyari Dhofier pondok pesantren merupakan sebuah asrama pendidikan Islam tradisional dimana para siswanya tinggal bersama dan belajar di bawah bimbingan seorang atau lebih guru yang lebih dikenal dengan sebutan Kyai. ${ }^{19}$ Sedangkan bagi Mastuhu pondok pesantren adalah lembaga pendidikan tradisional Islam (tafaqub fiddin) dengan menekankan pentingnya moral agama Islam sebagai pedoman hidup bermasyarakat sehari-hari. ${ }^{20}$

Dalam melihat pesantren secara definitif, ada stressing yang sangat penting dicermati yakni pesantren sebagai sistem. Artinya, menurut Raharjo pondok pesantren sebagai sumbu utama dari dinamika sosial, budaya dan keagamaan masyarakat Islam

\footnotetext{
${ }^{18}$ Harun Nasution etal., Ensiklopedi Islam Indonesia (Jakarta: Djambatan, 1992), hlm. 771.

${ }^{19}$ Zamahhsyari Dhofier, Tradisi Pesantren: Studi Tentang Pandangan Hidup Kyai (Jakarta: LP3ES, 1994), hlm. 44.

${ }^{20}$ Mastuhu, Dinamika Sistem Pendidikan Pesantren (INIS, Jakarta, 1994), hlm. 6.
} 
Vol. 13, No. 2, Oktober 2020

p-ISSN:2086 -0749

e-ISSN:2654-4784

tradisional, pesantren telah membentuk suatu subkultur yang secara sosio-antropologis bisa kita katakan sebagai masyarakat pesantren. ${ }^{21}$ Dapat dielaborasikan lebih jauh, bahwa apa yang disebut pesantren di situ bukan semata wujud fisik tempat belajar agama, dengan perangkat bangunan, kitab kuning, santri dan Kyainya. Tetapi juga masyarakat dalam pengertian luas yang tinggal di sekelilingnya, dan membentuk pola hubungan budaya, sosial dan keagamaan, di mana pola-polanya kurang lebih sama dengan yang berkembang atau dikembangkan di pesantren atau berorientasi pesantren. Kebudayaan masyarakat tersebut tak bisa dibantah memang dipengaruhi oleh pesantren dan diderivasi darinya. Dalam arti ini,

${ }^{21}$ M. Walid, Kepemimpinan K.H. Ach. Murakki Syah (Pengasub Pondok Pesantren Al-Qodiri) dalam Memberdayakan Masyarakat di Kabupaten Jember(Penelitian Depag 2007), hlm. 15. masyarakat sekitar tersebut adalah juga "bagian dalam" dari masyarakat pesantren.

\section{Agen Sosialisasi Gender}

Menrut David A. Goslin berpendapat "Sosialisasi adalah proses belajar yang di alami seseorang untuk memperoleh pengetahuan ketrampilan, nilainilai dan norma-norma agar ia dapat berpartisipasi sebagai anggota dalam kelompok masyarakatnya." 22

Lewat proses-proses sosialisasi, individu-individu masyarakat belajar mengetahui dan memahami tingkah pekerti-tingkah pekerti apakah yang harus dilakukan dan tingkah pekertitingkah pekerti apa pulakah yang harus tidakdilakukan (terhadap dan sewaktu berhadapan dengan orang lain) di dalam masyarakat.

\footnotetext{
22Ihrom, Bunga Rampai Sosiologi Keluarga. (Jakarta:Yayasan Obor Indonesia,2004. ). hlm. 30
} 


\section{Erfan Efendi}

Ringkas kata, lewat sosialisasi warga masyarakat akan saling mengetahui peranan masingmasing dalam masyarakat, dan kemudian dapat bertingkah pekerti sesuiai dengan peranan sosial masing-masing itu.

Menurut Ihromi menjelaskan gagasan Berger dan Luckman dalam sosialisasi dibedakan atas dua tahap yakni:

Sosialisasi primer sebagai sosialisasi pertama yang dijalani individu semasa kecil, melalui mana ia menjadi anggota masyarakat, dalam tahap ini proses sosialisasi primer membentuk kepribadian anak kedalam dunia umum dan keluargalah yang berperan sebagai agen sosialisasi. Sosialisasi sekunder, didefinisikan sebagai proses berikutnya yang memperkenalkan individu yang telah disosialisasikan ke dalam sektor baru dunia objektif masyarkat; dalam tahap ini proses sosialisasi mengarah pada terwujudnya sikap profesionalisme; dan dalam hal ini menjadi agen sosialisasi adalah lembaga pendidikan, peer group, lembaga pekerjaan, lingkungan yang lebih luas dari keluarga. ${ }^{23}$

Walau demikian, pada pihak lain, proses sosialisasi itu pun amat besar pengaruhnya bagi kehidupan warga masyarakat itu sendiri secara individual. Kiranya tanpa mengalami proses sosialisasi yang memadai tidak mungkin seorang warga masyarakat akan dapat hidup normal tanpa menjumpai kesulitan dalam masyarakat. Jelas, bahwa hanya dengan menjalani proses sosialisasi yang cukup banyak sajalah seorang individu warga masyarakat akan dapat menyesuaikan segalah tingkah pekertinya dengan segala keharusan norma-norma sosial.

Sosialisasi di sini secara khusus berfungsi untuk menyiapkan individu untuk memasuki kehidupan dalam masyarakat yang lebih dewa terutama di lingkungan

\footnotetext{
${ }^{23}$ Ihrom, Bunga Rampai Sosiologi Keluarga (Jakarta:Yayasan Obor Indonesia,2004). hlm. 32
} 
Vol. 13, No. 2, Oktober 2020

p-ISSN:2086 -0749

e-ISSN:2654-4784

pesantren. Pada tahap ini juga, sosialisasi gender akan menghasilkan system refrensi yang lebih tegas mengenai prilakuprilaku yang dianjurkan dan yang dilarang. Adapun prilaku yang dianjurkan seperti prilaku yang didorong dan diutamakan oleh masyarakat, sementara perilaku yang dilarang adalah perilaku yang dianggap tabu oleh masyarakat.Dengan kerangka sosialisasi tersebut, pesantren dapat dipandang sebagi lembaga social di mana proses sosialisasi gender pada tahap pasca anak-anak berlangsung. Dalam proses inidiedarkan seperangkat wacana atau ide-ide yang menyediakan pengertian bagi santri mengenai identitas mereka sebagai laki-laki atau perempuan. Lebih dari itu, proses tersebut juga memproduksi pesan-pesan, norma-norma, tumtuana tata aturan dan symbol-simbol yang memben- tuk system refrensi bagi perilaku santri berdasarkan gender mereka.

Kiai, nyai, ustad, ustadah, kabuleh dan semua struktur pengelola pesantren dipahami sebagai agen-agen sosialisasi gender. Agen sosialisasi tersebut dapat kita pahami sebagai orang-orang atau kelompok sosial yang menyediakan atau memberikan informasi terkain nilai-nilai dan perilaku yang berhubungan pesan-pesan gender. ${ }^{24}$ dalam kontek pesantren, sosialisasi gender dimungkinkan oleh peran yang diimainkan oleh Kiai, nyai, ustad, ustadah, kabuleh dan semua struktur pengelola pesantren sesuai degan posisi serta fungsi masing-masing.

\footnotetext{
${ }^{24}$ Linda L. Lindsey, Gender Roles: $A$ Sociological Perspective (New Jerse: Pearson aducation, Inc.,Upper Saddle River, 2005), hlm. 61
} 


\section{Erfan Efendi}

\section{Temuan Penelitian dan}

\section{Pembahasan}

1. Kepemimpinan Kyai Dan Nyai dalam Sosialisasi Gender

Kyai sebagai tokoh sentral mempunyai peran penting dalam lingkungan dan dinamika pesantren serta dinamika masyarakat. Selain sebagai pemimpin pesantren, Kyai mempunyai tugas utama sebagai guru dan pembimbing spiritual serta mempunyai kelebihan lain seperti dapat menyembuhkan penyakit, meramal, menguasai ilmu bela diri dan mempunyai kekuatan supra natural. Secara umum Kyai juga dipandang sebagai ulama karena Kyai dianggap menguasai ilmu agama secara mendalam dan mempunyai pengetahuan yang luas tentang Islam, walaupun pada kenyataannya pengetahuan mereka tentang agama dan Islam sangat beragam. Ada beberapa Kyai memang mempunyai pengetahuan yang luas dan mendalam tentang agama Islam tetapi tidak sedikit pula yang mempunyai pengetahuan terbatas dan hanya mengandalkan pada kewibawaan pribadi dan kewibawaan keluarga serta kekuatan supra natural yang dimilikinya.

Peran moderat yang dimainkan oleh pemimpin pondokpesantren

WahidHasyimKyai H. Jalal Sayuti yang memiliki otoritas kepemimpinan yang terlibat dalam setiap keputusan. Meskipun tidak mengajar dan juga tidak berinteraksi secara langsung dengan santri. Namun peran Kyai disini sangat Nampakterbukti dengan adanya sosialisasi gender yang diterapkan Kyai dan para pengurus pondok di pesantren tersebut mempunyai karakteristik yang berbeda. Misalnya seperti kyai mempunyai kapasitas untuk melakukan perubahan atau sebaliknya penguatan terhadap diskursus gender yang telah ter- 
Vol. 13, No. 2, Oktober 2020

p-ISSN:2086 -0749

e-ISSN:2654-4784

konstruksi dalam lingkungan pesantren. Kyai selalu memberikan penyadaran kepada santri untuk memperkuat ajaran agama. Perankyai dan nyai dalam studi ini menghendaki adanya pendalaman kitab-kitab yang telah ditentukan untuk kepentingan pendidikan dipesantren. Dalam konteks sosialisasi nilai-nilai kesetaraan, kyai dan nyai telah menguatkan komitmen mereka melalui tindakan-tindakan yang harus dan perlu dilakukan untuk kepentingan peningkatan pesantren, bagi kyai dan nyai menanamkan prinsip bahwa apa yang menurut pengurus dan santri sekirannya baik untuk dilakukan lebih-lebih dalam mengembangkan mutu pesantren baik dalam aspek pendidikannya, sosial dan budaya, dalam hal ini Kyai sangat mendukung asalkan tidak bertentangan dengan ajaran agama Islam.

Metode penguatan gendersecara tekstual yang dilakukan pimpinan pondok Pesantren WahidHasyim adalah dengan mempertahankan tradisi yang sudah terlembaga didalam pesantren selama bertahun tahun. Metode ini memanfaatkan teks-teks kitab dan ketentuan nabi. Metode ini dilakukan dengan tiga cara diantaranya: 1). Pengajian yang disampaikan secara terus menerus 2). Penekanan materi gender tradisional dalam pelajaran yang dilakukan di setiap lembaga masingmasing seperti: Madrasah Diniyah, Madrasah Tsanawiyah, Madrasah Aliyah. 3). Melalui pengajian mingguan, dalam kegiatan ini bukan hanya santri yang mengikutinya, melainkan para penduduk sekitar juga ikut serta menjadi peserta dalam pengajian tersebut. 4). 


\section{Erfan Efendi}

Khutbah dan khutbah nikah, dalam sosialisasi ini lebih menitikberatkan pada mendialogkan pesan dan muatan teks-teks klasik dengan perkembagan kondisi sekarang atau banyak orang menyebutnya masyarakat melenial dalam rangka mencari pemahaman dan wawasan baru yang lebih memadai.

Dengan adanya beberapa sosialisasi di atas, maka struktur analisi dalam proses sosialisasi gender dapat digambarkan dengan krangka konseptual sebagai berikut:

Proses Sosialisasi Gender Di Pesantren Wahid Hasyim terdiri dari beberapa agen, antara lain : Kyai, Nyai, Ustad/Ustadah, Santri, dan Masyar. Pesantren yang dipandang sebagai lembaga social dengan ciri khasnya yang khusus.

Dalam proses sosialisasi tersebut, masing-masing agen sosialisasi memainkan perannya berdasarkan konteks posisi social mereka masing-masing. Penekanan diberikan pada peran kiai, nyai. Proses sosialisasi tersebut melibatkan distribusi pengetahuan dan kekuasaan antara para anggota lingkungan pesantren.

$$
\text { Sosialisasi memproduksi }
$$

diskursus dalam lingkungan pesantren. Diskursus tersebut meliputi berbagai elemen termasuk nilai-nilai, norma-norma, ajaran, model atau contoh perilaku, aturan serta pesan-pesan gender lainnya.

Adapun yang berkenaan dengan proses pencalonan menjadi ketua pengurus menjadi hak semua santri, baik putra maupun putri. Santri putra dan putri memiliki hak untuk dipilih dan memilh.Terdapat perbedaan yang cukup jauh antara jumlah santri putra dan putri. Santri putra lebih sedikit dibandingkan dengan santri putri.Pengangkatan jabatan sebagai ustadz/ ustadzah di Madrasah diniyah dan guru di Madrasah Ibtidaiyah ditentukan sesuai pres- 
Vol. 13, No. 2, Oktober 2020

p-ISSN:2086 -0749

e-ISSN:2654-4784

tasi, level pendidikan di pondok, dan tingkat kemampuan para santri calon ustadz/ ustadzah dan guru. ${ }^{25}$

2. Implementasi Keseteraan

Gender Pada Peraturan

Pesantren

Santri yang benar-benar baru dan sama sekali belum pernah mondok di pesantren pasti bakal kaget dengan aktivitas di pesantren. Mulai dengan kebiasaan hidup sehari-hari hingga jadwal ngaji yang padat. Nggak sedikit juga santri pesantren yang pernah kepikiran untuk boyong alias keluar dari pesantren. Tapi keinginan itu sirna seiring dengan

\footnotetext{
${ }^{25}$ Hasil wawancara pada tanggal 27 Desember 2016 jam 13.00 dengan pengasuh Pondok Pesantren Wahid Hasyim. Peneliti pada saat alhamdulillah diterima dengan baik oleh kiai, bahkan kita disuruh melanjutkan untuk melakukan pengkajian yang lebih serius supaya dengan hasil penelitian in menjadi kontribusi terhadap pandangan masyarakat yang selama ini dipandang miring terkait dengan realisasi gender yang ada di pesantren.
}

tekad yang kuat.Setiap tempat pasti punya aturan tersendiri. Begitu juga dengan pesantren. Bagi yang belum pernah merasakan hidup di pesantren, pasti bakal kaget dengan sederet peraturan yang ada di pesantren. Mulai dari ngaji hingga izin pulang juga diatur.

Tidak ada perbedaan gender di Pondok Pesantren Wahid Hasyim. Data wawancara menunjukkan, tidak terdapat masalah perbedaan gender di lingkungan Pondok Pesantren Wahid Hasyim, baik yang berkaitan dengan masalah peraturan, kewajiban, dan hak para santri WahidHasyim.Santri putra dan putri dapat saling berkomunikasi dan berdiskusi bersama sesuai dengan tempat dan waktu yang telah ditetapkan. Peraturan pondok untuk santri putri dan putra dibuat sama tanpa memandang gender.Misalnya: jam 


\section{Erfan Efendi}

pulang ke pondok untuk santri putri pada jam 05.30 begitupun untuk santri putra. Mereka harus mengikuti kegiatan pondok sampai pada jam 10.00 p.m. pagi harinya, mereka akan kembali mengikuti kegiatan pondok mulai jam 05.30-06.30. ${ }^{26}$

\section{Implementasi Keseteraan}

Gender Pada Prilaku Santri

Adanya berbagai forum yang disampaikan secara terus menerus mempertegas ajaran $\mathrm{Al}-$ lah menetapkan perbedaan antara laki-laki dan perempuan. Perbedaan itu merupakan isyarat bahwa Allah memperlakukan antara lakilaki dan perempuan secara berbeda dalam aspek tertentu seperti misalkan pacaran, berzina, mencuri, membunuh dan minumminuman keras. hal ini menjadi program rutinitas yang dilakukan Kyai pada waktu yang sudah ditentukan semisal habis sholat

\footnotetext{
${ }^{26}$ Hasil wawancara pada tanggal 29 Desember 2013 pada jam 09.00 dengan ustazdah Sulis sebagai bendahara pengurus.
}

Magrib dan selesai sholat Subuh, dengan metode ceramah yang dilakukan Kyai namun tidak menutup kemungkinan dalam majlis tersebut semua santri berkumpul menjadi satu.

Kesetaran sosial (gender) dipondok pesantren WahidHasyim juga muncul hal ini dibuktikan dengan adanya pengajaran yang dilakukan oleh pengurus baik laki-laki dan perempuan dan juga para ustadz dan ustazdah baik pada tingkat Madrasah Ibtidaiyah, Madrasah Tsanawiyah, dan Ma'had Ali, dalam hal ini, metode yang digunakan dengan menekankan tema-tema yang telah lama mapan dalam teks ajaran pesantren dan kemudian dielaborasi dengan menguatkan muatan ajaran gender tradisional dalam teks-teks kitab tersebut.

Sistem di Pondok Pesantren Wabid Hasyim sudah mengikuti perkembangan zaman. Seperti,Placement test, pergantian pengurus dilakukan secara demokratis tanpa ada 
perbedaan antara laki-laki dan perempuan semuanya bisa berpartisipasi dalam mencalonkan diri sebagai kandidat pengurus, dan juga adanya pengembangan babasa asing (Arab-Inggris). ${ }^{27}$

Dalam hal ini juga, Pondok Pesantren WahidHasyim melakukan pendampingan terhadap masyarakat dengan bentuk pengabdian terhadap masyarakat yang dilakukan selama dua tahun, kegiatan ini bukan hanya berlaku pada kaum laki-laki saja melainkan perempuan juga ikut serta dalam pelaksanaan pengabdian tersebut. Misalnya seperti adanya organisasi kemasyarakatan Baitul Ma'had di sini peran gender sangat nampak dengan mengisi pengajian, mengajar dan diskusi yang diikuti

${ }^{27}$ Hasil wawancara pada tanggal 27 Desember 2016 jam 13.00 yang bertempat di pondok pesantren WahidHasyim dengan ustad Mahfud yang menjabat sebagi pengurus dan ustadz di pondok pesantren WahidHasyim. oleh masyarakat setempat dan pendampingan terhadap TPA di kawasan Jogja.

Pembatasan bubungan pertemuan antara santri putra dan putri diserabkean masing-masing kepada para santri. Karena sang pengasub sudab menganggap babwa mereka mampu mengontrol diri masingmasing. Dikarenakan sebagian besar dari mereka adalah para mahasiswal mahasiswi dari berbagai Universitas yang sudah mencukupi umur dan pemikiran kedewasaan. ${ }^{28}$

Secara umum pondokpondok pesantren memisahkan pondok (asrama) santri putra dan santri putri. Demikian juga untuk kegiatan belajar di madrasah, antara santri putra dan santri putri dipisah. Walaupun demikian beberapa kegiatan di pondok

\footnotetext{
${ }^{28}$ Hasil wawancara pada tanggal 28 Desember 2016 jam 15.00 pada saat itu peneliti bersama-sama mendatangi ustadzah Binti Afifah (menjabat sebagai sekertaris orgabisasi putri), ustazdah Binti Afifah senang ketika didatangi peneliti, karena bagi ustadzah Binti Afifahgender merupakan kajian yang tepat untuk dilakukannya penelitian lebih-lebih di Pondok Pesantren Wahid Hasyim.
} 


\section{Erfan Efendi}

pesantren dilakukan oleh santri putra dan santri putri secara bersama-sama yang memungkinkan mereka untuk berhubungan dan berkomunikasi, seperti kegiatan sholat berjama'ah, pengajian-pengajian umum atau kegiatan bersama untuk memperingati hari-hari besar Islam dan lain sebagainya.

Hubungan dan komunikasi antara santri putri dengan santri putra di pondok pesantren Wabid Hasyim sangat sangata sulit dan dibatasi walaupun ada kegiatan bersama yaitu sholat berjama'ah. Komunikasi hanya bisa dilakukan oleh santri putri yang berstatus ustadrah dengan santri putra yang sudab berstatus ustad\%. Itupun banya untuk masalah-masalah yang penting yang berkaitan dengan kegiatan pengajaran di pondok pesantren. ${ }^{29}$

Hal diatas menunjukkan, walaupun sudah dibuat peraturan yang membatasi komunikasi dan hubungan sosial antara santri putra dan putri serta ancaman sanksi bagi yang melanggar, tetapi ada beberapa kasus pelanggaran

\footnotetext{
${ }^{29}$ Hasil wawancara pada tanggal 28 Desember 2016 jam 15.00
}

yang dilakukan oleh santri putra dan santri putri. Hal ini dapat difahami karena para santri yang belajar di pondok pesantren adalah santri remaja yang dalam masa-masa saling tertarik pada lawan jenis. Hubungan cinta antara santri purta san santri putri biasanya dilakukan melalui surat atau pada saat mereka pulang ke rumah masing-masing. Bila hubungan cinta atau pacaran antara santri putra dan santri putri ini diketahui oleh pengurus pesantren, maka santri mendapat sanksi yaitu santri bisa digunduli dan dikembalikan kepada orang tua dengan tidak hormat. Pelanggaran yang disebabkan oleh hubungan cinta antar santri ini jumlahnya tidak banyak karena beban dari sanksi sosial (rasa malu) ini lebih berat dibandingkan sanksi fisik.

\section{Simpulan}

Pemahaman konvensional terhadap Al-Qur'an dan Sunnah 
memberi kesan supremasi laki-laki atas perempuan, sementara pemahaman yang lebih liberal memberi kesan kemitra sejajaran laki-laki dan perempuan. Pemahaman konvensional mengharuskan pemahaman liberal yang menekankan perlunya menjawab tantangan zaman dengan mengedepankan mashaalih mursalah. Dari itu, persoalan gender atau kemitra sejajaran antara laki-laki dan perempuan yang sebelumnya dikenal dengan peningkatan kedudukan peran perempuan dalam Islam semakin menarik banyak kemajuan dan keberhasilan.

Terdapat dua orientasi dalam mensosialisasikan gender di pesantren, yaitu: pertama, menguatkan normativitas peranperan gender. Peran ini dilakukan oleh sebagian besar para kyai, nyai, dan guru. Kedua, mengedepankan tekstualitas peran gender. Motif ini dilakukan oleh sebagian kecil guru madrasah dan badal kyai serta nyai ketika melakukan pengajian di pesantren.

\section{Daftar Pustaka}

Haedari, Amin et al. Masa Depan Pesantren. Jakarta: IRD Press.2004.

Zein, Hefni.Masa Depan Pesantren. Jember: Artikel Baitul Amin. 2005.

Thohir, Umar Faruq. Etika Islam dan Tranformasi Global. Yogyakarta: CV Pustaka Ilmu Group. 2013.

M. E chol, John dan Shadily, Hasan.Kamus Inggris Indonesia. Jakarta: Gramedia. 1993.

Megawangi, Ratna.Membiarkan Berbeda? Sudut pandang Baru Tentang Relasi Gender, cet. 2.Bandung: Mizan. 1999.

Neufeldt, Victoria ed. Webster's New World Dictionary. NewYork: Webster's New World Clevenland. 1984. 


\section{Erfan Efendi}

Tiemey, Helen ed.Women's Studies Encyclopedia, vol. 1.New York: Gren Wood Press.

Steans, Jiil.Gender and InternationalRelations. London: Polity. 1998.

Luttle, Lisa.Encyclopediaof Feminism. New York: Facts on filepublication. 1986.

Majid, Nurkholis.Bilik-bilike Pesantren. Jakarta: Paramadina. 1997.

Dhofier, Zanakhasary.Tradisi Pesantren: Studi Pandangan Kyai. Jakarta: LP3ES. 1994.

Gontor.Biografi KH. Imam Zarkasi dari Gontor Merintis Pesantren Modern. Ponorogo: Gontor Press. 1996.

Nasution, Harun etal.Ensiklopedi Islam Indonesia. Jakarta: Djambatan. 1992.

Dhofier, Zamahhsyari.Tradisi Pesantren: Studi Tentang Pandangan Hidup Kyai. Jakarta: LP3ES. 1994.

Mastuhu. Dinamika Sistem Pendidikan Pesantren. INIS, Jakarta. 1994.

M. Walid. Kepemimpinan K.H. Ach. Muzakki Syah (Pengasuh Pondok Pesantren Al-Qodiri) dalam Memberdayakan

Masyarakat di Kabupaten Jember. Penelitian Depag. 2007. 